\title{
Effect of Technology Enhanced Language Learning on Vocabulary Acquisition of EFL Learners
}

\author{
Imtiaz Hassan Taj (Corresponding author) \\ University of Jeddah, Jeddah 21361, PO Box: 110324, Kingdom of Saudi Arabia \\ E-mail: imtiaz468ht@gmail.com
}

Fatimah Ali

Center for Modern Languages and Human Sciences, Universiti Malaysia Pahang, Lebuhraya Tun Razak, Pahang 26300, Malaysia

E-mail: tym@ump.edu.my

Muhammad Aslam Sipra

King Abdulaziz University Jeddah 21589, Kingdom of Saudi Arabia

E-mail: makhan6@kau.edu.sa

Waqar Ahmad

University of Jeddah, Jeddah 21361, PO Box: 110345, Kingdom of Saudi Arabia

E-mail: waqar22@gmail.com

Received: 14-12-2016

Published: 01-05-2017
Accepted: 31-01-2017

doi:10.7575/aiac.ijalel.v.6n.3p.262 URL: http://dx.doi.org/10.7575/aiac.ijalel.v.6n.3p.262

\begin{abstract}
The study was conducted to investigate the impact of a model, created with the help of computer and mobile phone, on the EFL vocabulary learning of the students at a public university on a Preparatory Year Program. The study used a quasi-experimental pretest posttest control group design. The participants were 122 students in their first year at a public university. Half of them $(N=61)$ were male and half were female $(N=61)$. Six weeks treatment period involved vocabulary learning activities presented through PCs in the language laboratory and receiving multi-glossed vocabulary cards on the mobile phones through a social networking mobile phone application WhatsApp. Findings suggested that performance of treatment group was significantly better than that of control group on achievement posttest. The impact of treatment was found gender neutral as male and female participants benefitted from it alike.
\end{abstract}

Keywords: MALL, WhatsApp, Technology Assisted Language Learning, EFL vocabulary Instruction, CALL

\section{Introduction}

From EFL reader's perspective, new words pose immense challenge in the process of reading. Role of the vocabulary is absolutely crucial for successful reading comprehension. It is the primary mediator between text and reader. Therefore, success or failure of the reading process may depend on knowledge of vocabulary or absence of it (Barrot, 2013; Birch, 2014; Hirschel \& Fritz, 2013; Kang, Kang, \& Park, 2012; Nation \& Meara, 2002; Stockwell, 2010). Vocabulary is such an important factor in the reading process that its instruction cannot be left out of teacher's consideration.

Technology has been found helpful in teaching vocabulary. Possibilities of multi-glossed and multi-modal presentation of vocabulary have important implications for vocabulary instruction (Chun \& Plass, 1996; Gorjian, 2012; Rezaee \& Shoar, 2011; Yun, 2011). Vocabulary assumes huge importance in Saudi EFL reading context. Because Saudi culture has been identified as distinctly an oral culture and not a literate one. The Arabic language is highly contextualized language in which each word has rich contextual connotations (Zaharna, 1995). Reading is a foreign skill to Saudi students. They seem disinterested in the learning process generally and particularly in EFL reading (Morris, 2011). The performance of students in reading comprehension suffers mainly because of their poor vocabulary knowledge. Presence of too many new words increases anxiety. Thus, raising the Affective Filter (Dulay \& Burt, 1978; Krashen, 1981) which seriously impedes the process of reading comprehension. Technology can provide help in vocabulary learning as it allows teachers to present vocabulary in multimodal ways. The present study was undertaken to devise a model of preteaching vocabulary with the help of technology. Technological intervention used in this study had two parts. Firstly, multi-glossed lexical items were sent to the participants through WhatsApp, a social networking application, which has been identified as a potentially valuable learning platform (Al Shekaili, 2016; Lai, 2016; Plana, Gimeno, Appel, \& Hopkins, 2013). Secondly, same vocabulary cards were presented on the PCs in the language laboratory along with other vocabulary learning activities. The use of computer assistance in language learning is a well-established field in language learning (Chapelle, 2001; Dina \& Ciornei, 2013; Johnson, Perry, \& Shamir, 2010). No study could be located in the literature that employed combination of WhatsApp and PCs to pre-teach EFL learners at Preparatory Year Program in Saudi Arabia. There is a gap in literature and the present study is expected to fill it. 


\section{Literature Review}

Vocabulary instruction has been identified as an important part in reading process. Different strategies have been advocated to achieve this end. One such strategy is repeated reading that has been found helpful (Han \& Chen, 2010). Skipping unimportant words can be another helpful strategy but it must be used sparingly as the learners might develop a habit of skipping every challenging word (Birch, 2014). Bottom up strategies such as word attack and meaning making are also useful as they prepare ground for use of top down strategies (Lems, Miller, \& Soro, 2009). Likewise, Barrot (2013) also considers the lexical aspect of reading as an important one for comprehension. Making the patterns salient in vocabulary can make its assimilation easy because human mind seems to store information on different aspects of words in patterns (Willis, 2008). The question of depth and breadth of vocabulary is also important. Evidence suggests that breadth of vocabulary is more important than depth of vocabulary in the reading comprehension process (Moinzadeh \& Moslehpour, 2012). Although, a similar study by Kang et al. (2012) reported contrasting results. It concluded that vocabulary depth is more important in reading process that vocabulary breadth. The results may be compared keeping in mind two different contexts of these studies and the subjects' age group. The first study had adults as subjects while the second study had first and second graders as subjects. Both studies, though differed in one aspect, they reported one similar finding that depth and breadth were highly correlated aspects of reading process. Technology has been put to use in vocabulary instruction with encouraging results. A review of available literature in this respect is presented in the following section.

\subsection{Vocabulary and Computers}

Computers are wonderful machines with remarkable capabilities of presenting, storing and retrieving information. They have been used in vocabulary instruction as assistive tools with encouraging results. In the context vocabulary acquisition words can be learned quickly if they are made salient. In this study, Ecalle, Magnan, and Calmus (2009) tested the same idea. Findings suggested that the subjects benefitted from this type of salience. Similarly, Ecalle, Kleinsz, and Magnan (2013) found grapho-syllabic training helpful in word recognition. Likewise, a meta-analysis of ten studies by Montero Perez, Van Den Noortgate, and Desmet (2013) reported significant gains in vocabulary through the use of captioned videos. It highlighted the importance of multimodal presentation in vocabulary instruction. In the opinion of Hirschel and Fritz (2013), computers can present information in varied contexts which is valuable for learners. They reported $12 \%$ higher gains in vocabulary learning for the subjects in the treatment group as compared to the comparison group who were taught through pen and paper method. The gains achieved through computer assisted learning have been found longer lasting than other methods (Lin, Hsiao, Tseng, \& Chan, 2014). Computers have become more capable after the advent of the Internet. Additionally, Mustafa, Sain, and Razak (2012) investigated the impact of the Internet on learning vocabulary. Experimental group comprised of fifteen secondary school students. They read texts online and completed accompanying activities while the comparison group $(N=15)$ studied same material on paper. The findings showed that comparison group performed significantly better than did the comparison group.

\subsection{Hypertext Glosses}

A gloss can defined as a clarification, rendition, annotation or explanation of a lexical item in a text to make it comprehensible for the reader. The gloss can be presented in the margins or footnote. Vocabulary glosses presented in hypertext environment have been found valuable in vocabulary learning. A meta-analysis of ten studies exploring the impact of hypertext glosses by Yun (2011) reported an effect size of +0.46 which highlights the value of the technique. Glosses with pictures which are referred to as pictorial glosses have also been found effective in vocabulary (Chun \& Plass, 1996). Video glosses were found even more beneficial than pictorial glosses (Rezaee \& Shoar, 2011). Comprehensive gloss condition which entails L1, L2 definitions, static pictures, audio and video glosses presented together has been more effective than one or two types of glosses (Marzban, 2011). Impact of audio glosses' as reported in Beechler and Williams (2012) was remarkably significant. In another study Azari, Abdullah, Heng, and Hoon (2012) compared the effect of L1 and L2 glosses with only L1 glosses and no glosses scenarios. The results suggested that students benefitted more from bilingual glosses than other two conditions. Since the idea of glossed vocabulary is quite established in literature, the researchers have been trying to exploit it by investigating it from different angles. I. Chen and Yen (2013) investigated different positioning of glosses such as pop up, in text, and end page. The findings suggest that pop up glosses were found more effective than other two formats.

To sum up presentation of glossed vocabulary assists in its acquisition. Hypertext provides different presentation options and it is the teachers' job to choose from these options according to their teaching contexts. All studies reviewed reported positive impact of the glosses which make them a viable option in planning and dispensing vocabulary instruction. This glossed vocabulary needs to be presented. Until recently, learning material had two modes of delivery either paper or computers. Technological innovation has made another mode of delivery available that is mobile phones. Since Chickering and Ehrmann (1996) used the term Mobile Assisted Language Learning (MALL) first time two decades ago, it has been flourishing as a research field. The following section reviews some of the lessons learned in this field.

\subsection{MALL and Vocabulary}

Markets have been flooded with new generation smart phones which are available on exceedingly low prices. The android technology has revolutionized the way people communicate. The play stores are brimming with applications. Educators have not been oblivious to these new affordances made available. Mobile phones have been identified as potential platforms that can assist in language teaching learning process (Abdullah, Hussin, Asra, \& Zakaria, 2013; Chickering \& Ehrmann, 1996; Demouy \& Kukulska-Hulme, 2010; Jarvis $\&$ Achilleos, 2013). Use of mobile phones for vocabulary and grammar instruction is already the main focus in the field (KukulskaHulme \& Shield, 2008). In most of the studies, in past two decades on MALL, the vocabulary learning skill has been the target skill (Duman, Orhon, \& Gedik, 2015; H. Kim \& Kwon, 2012).

Comparing different modes of vocabulary presentation that is paper based, online and through mobile phones Nikoopour and Kazemi (2014) found that mobile phone delivery option was the best among the three modes investigated. In another study, one component of a communication skills course was delivered through mobile phones. The subjects didn't have face to face interaction with teacher. All 
interaction among the subjects and the teacher was through mobile phone. The study reported significantly improved performance of the subjects in this component of the course (Abdullah et al., 2013). Jarvis and Achilleos (2013) reported results of a qualitative study which explored the learners' preferences in use of the multimedia for second language learning purposes. Majority of the subjects showed their preference for mobile language learning. Mobile phones are changing at astonishing speed, early draw backs of small screens and audio video output quality (Miangah \& Nezarat, 2012) are no longer there. The subjects in the study by Palalas (2011) reported that doing learning activities on mobile phones was fun and they felt motivated to complete the tasks. Mobile phones offer exciting applications such SMS, microblogging and social networking (Yang, 2013). Mobile learning activities provide ubiquitous opportunities for learners to receive practice free of constraints of time and place (Jarvis, 2015). After evaluating three pilot projects in Asian countries Valk, Rashid, and Elder (2010) concluded that mobile phones can be used as crucial tool to overcome challenges of distance and lack of infrastructure. Similar view are shared by Jones (2011). Mobile learning has the promise of creating an environment where learners can switch from one learning scenario to the other with ease and without experiencing any disruption (Wong, 2012). Basoglu and Akdemir (2010) used mobile phone as delivery mode for vocabulary cards. The findings suggested that experimental group outperformed the comparison group. Similar results were reported by Alavinia and Qoitassi (2013). N. S. Chen, Hsieh, and Kinshuk (2008) investigated the impact of different types of glossed vocabulary on vocabulary acquisition of 156 students who were aged between 19 and 22 years. The vocabulary items were sent through mobile phones. The findings suggested that the students benefitted more when textual and pictorial glosses were presented together. These results support the assumptions of dual coding theory.

The study by $\mathrm{Lu}$ (2008) involved thirty subjects and it was carried out in a high school setting in Taiwan. The subjects were divided into the treatment and the comparison groups. The treatment which was delivery of vocabulary items through SMS lasted for two weeks. Findings indicated that treatment group performed better than did comparison group on posttest. However, the impact withered out in the delayed posttest. It can be pointed out that the sample size was very small and the treatment duration was also very short. In another study Alemi, Sarab, and Lari (2012) reported contrasting results where immediate posttest reported no significant difference but treatment group performed better in delayed posttest than did the comparison group. Two studies were conducted in two different settings. Cultural differences and difference in sample size might be the reasons for these results.

In this study, Motallebzadeh and Ganjali (2011) investigated the effect of mobile assisted learning on EFL vocabulary acquisition. Vocabulary was sent as SMS to mobile phones of the participants. Treatment group performed better than did the comparison group. In a similar study, Hayati, Jalilifar, and Mashhadi (2013) reported that the treatment group who received English idioms through SMS stated that the experience was satisfying and motivating for them. Interestingly, $80 \%$ of them were not willing to pay for the reply SMS.

Likewise, H. S. Kim (2011) reported positive results in favor of SMS delivery mode of vocabulary items. Though the subjects in this study valued the mobility feature of the treatment they were of the opinion that words sent through SMS should not be too many. They felt that too many messages disrupted their social and family time. These aspects of the tasks also need careful attention. Similar views are expressed by Stockwell and Hubbard (2013) that MALL tasks should be concise, interesting, captivating and short. Also the cultural and social sensitivities must be given due consideration. MALL tasks are effective and teachers have positive perception of the possibilities offered by mobile technology (Oz, 2015).

Sandberg, Maris, and de Geus (2011), reported positive results from their study that evaluated the use of mobile devices to learn location specific vocabulary. The group that retained their mobile devices for a fortnight performed better than the group that turned in their devices after their visit to location. It suggests that more practice is important for learning new vocabulary.

Only three studies could be located that investigated computer assisted vocabulary acquisition in Saudi context. AbuSeileek (2008), evaluated the effect of the hypermedia glosses on vocabulary learning of Saudi students. Findings indicated that learners benefitted from treatment. Regarding the positioning of the glosses the margins or the bottom of the page were identified as best places. Hussain (2011), studied the relative effect of three types of gloss conditions on the vocabulary retention of students in a Saudi university. Condition one was text and audio. Condition two had text, audio, and picture. Condition three had text, audio and video. Findings indicated that condition two was found more helpful than other two combinations. The third study by Al-Jarf (2007) evaluated the effect of online vocabulary instruction on vocabulary learning of Saudi female students. The study reported significantly beneficial impact of online instruction on vocabulary learning.

To sum up this section mobile phones have been used as important tools to help in vocabulary instruction. Barring one or two isolated cases in all studies reviewed, the mobile phones proved helpful in vocabulary instruction.

\section{Research Questions and Hypotheses}

The present study sought answers to the following research questions.

1. What impact does the Hybrid Model have on the EFL vocabulary learning of students on Preparatory Year Program (PYP) at a public university?

2. How does the Hybrid Model effect the EFL vocabulary learning of male and female learners on Preparatory Year Program (PYP) at a public university?

The study tested the following hypotheses for answers to the above-stated questions.

1. The Hybrid Model has no impact on the EFL vocabulary learning of students on Preparatory Year Program (PYP) at a public university.

2. The Hybrid Model has an impact on the EFL vocabulary learning of students on Preparatory Year Program (PYP) at a public university. 
3. The impact of the Hybrid Model on the EFL vocabulary learning of students on Preparatory Year Program (PYP) at a public university, is gender neutral.

4. The impact of the Hybrid Model on the EFL vocabulary learning of students on Preparatory Year Program (PYP) at a public university, is not gender neutral.

\section{Methodology and Materials}

The study used quasi experimental pretest posttest control group design. The sample selection could not be randomised because of administrative constraints. However, assignment of groups to the treatment or the control condition was randomised. Preformed intact groups of students were the participants (Fraenkel, Wallen, \& Hyun, 1993). The participants were given a pretest before the start of treatment to establish the baseline equality of the groups in terms of their language performance. A posttest was given at the completion of the treatment period which lasted for six weeks.

\subsection{Participants}

The study had 122 students as participants who were enrolled on Preparatory Year Program (PYP) at a public university. Their ages fell between 19 and 22 years. Half of them were male $(N=61)$ and half were female $(N=61)$. Overall, there were four preformed groups of participants, two male groups and two female groups. They had similar language learning experiences prior to entering university as they had completed same secondary school education. They had been studying English as foreign language for six years at school level. At the time of study they were in the second semester of their two semester general English course in their Preparatory Year at the university.

\subsection{Treatment and Procedure}

The material used for treatment was taken from the English course book New Headways Plus Intermediate Student Book (Soars, Soars, \& Wheeldon, 2014). Vocabulary for pre-teaching was taken from first ten reading passages. It was identified, as important for the comprehension of the passages used, by ten expert teachers who had vast teaching experience in EFL. The vocabulary, thus identified, comprised of 87 words. The treatment groups and the control groups were taught by four experienced teachers, two teachers from male campus and two from female campus. One group from each campus was randomly assigned to the treatment condition and one group to the control condition. The control groups, both female and male, learned same vocabulary items through traditional methods by teachers using pen and paper materials.

The treatment group met twice a week for one and a half hours session five days a week for six weeks according to their preset schedules. The vocabulary learning activities were completed as a preparation to deal with reading passages which were presented after these activities. The treatment had two parts. Firstly, the vocabulary items were glossed. Glosses included L1, L2 definitions, a picture, and an example sentence (Chun \& Plass, 1996). Help was taken from an Arab colleague to verify the L1 definitions as Arabic is not the first language of the researcher. For L2 definitions dictionary was used. Images were downloaded from Google images. Vocabulary cards of the glossed vocabulary were created using PowerPoint application. Teachers teaching treatment groups created groups on WhatsApp, a social networking application, with all participants of the treatment group as members. They sent these cards to the students on their mobile phones through WhatsApp. A sample vocabulary card is presented below in figure 1 .

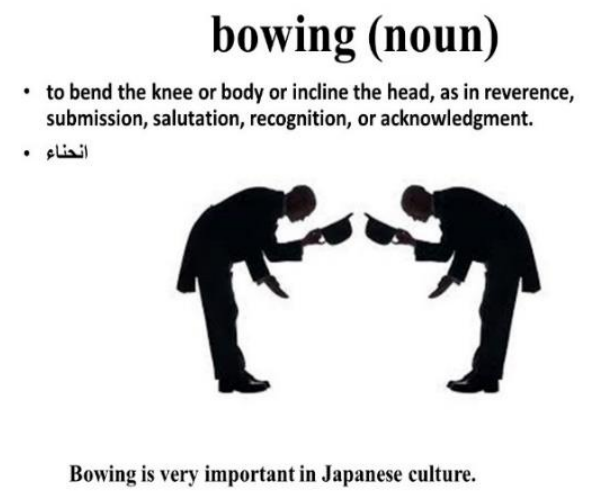

Figure 1. A sample vocabulary card

Frequency of sending the cards was kept to maximum five at a time. The cards were sent during days prior to the sessions in the language laboratory. In this regard an effort was made to avoid burdening the students when they received these cards in different social scenarios. So when they came to the language laboratories for reading sessions they had already received the vocabulary items.

Secondly, the vocabulary quizzes (Burt, Peyton, \& Van Duzer, 2005) and word puzzles (August, 2011) were created using a software hot potatoes (version 6.3.0.5.) which is available on the internet free of cost. It was downloaded from https://hotpot.uvic.ca/. The screen shots of these activities are presented in figures 2 and 3 below. Working on crossword puzzles and vocabulary quizzes served as extended practice measure. These activities were used in the language laboratory for practice and they were also given to the students on CDs for practice at home. 


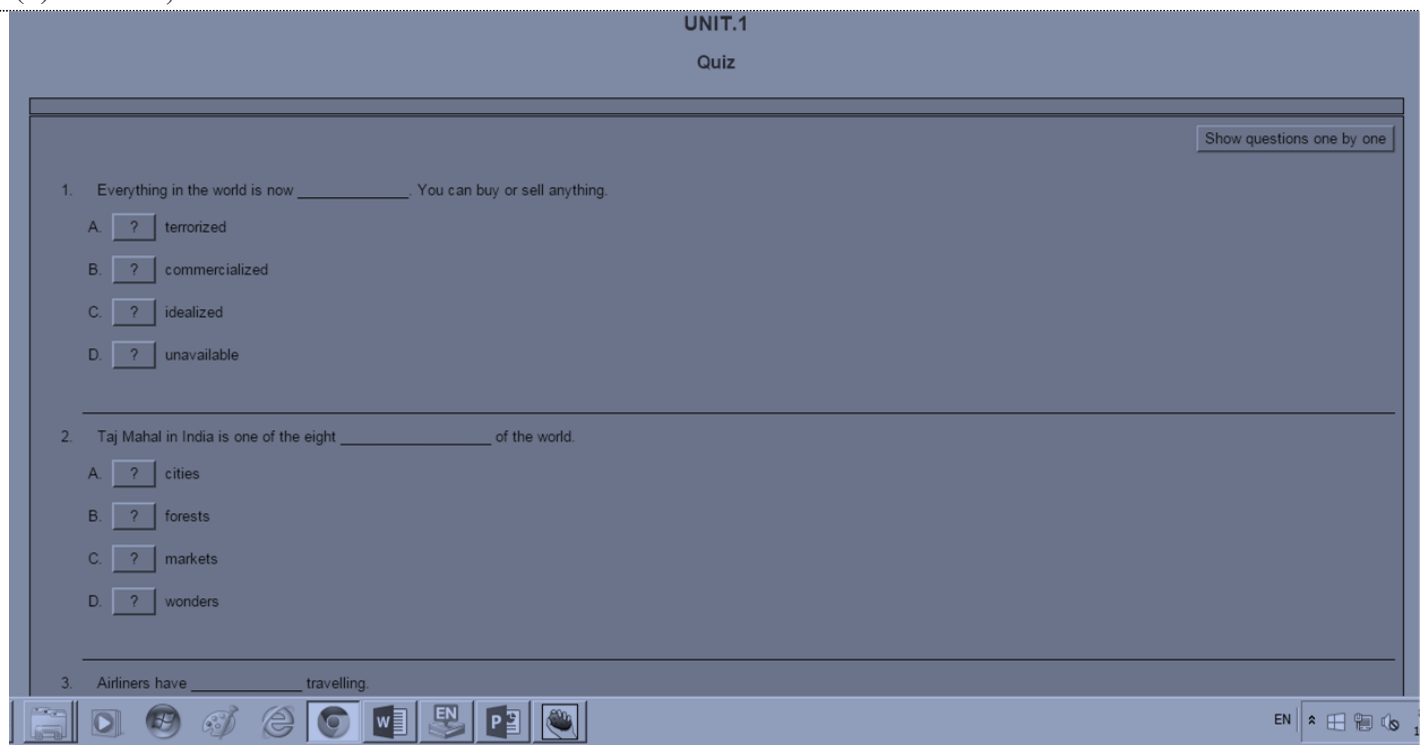

Figure 2. A screen shot of vocabulary quiz

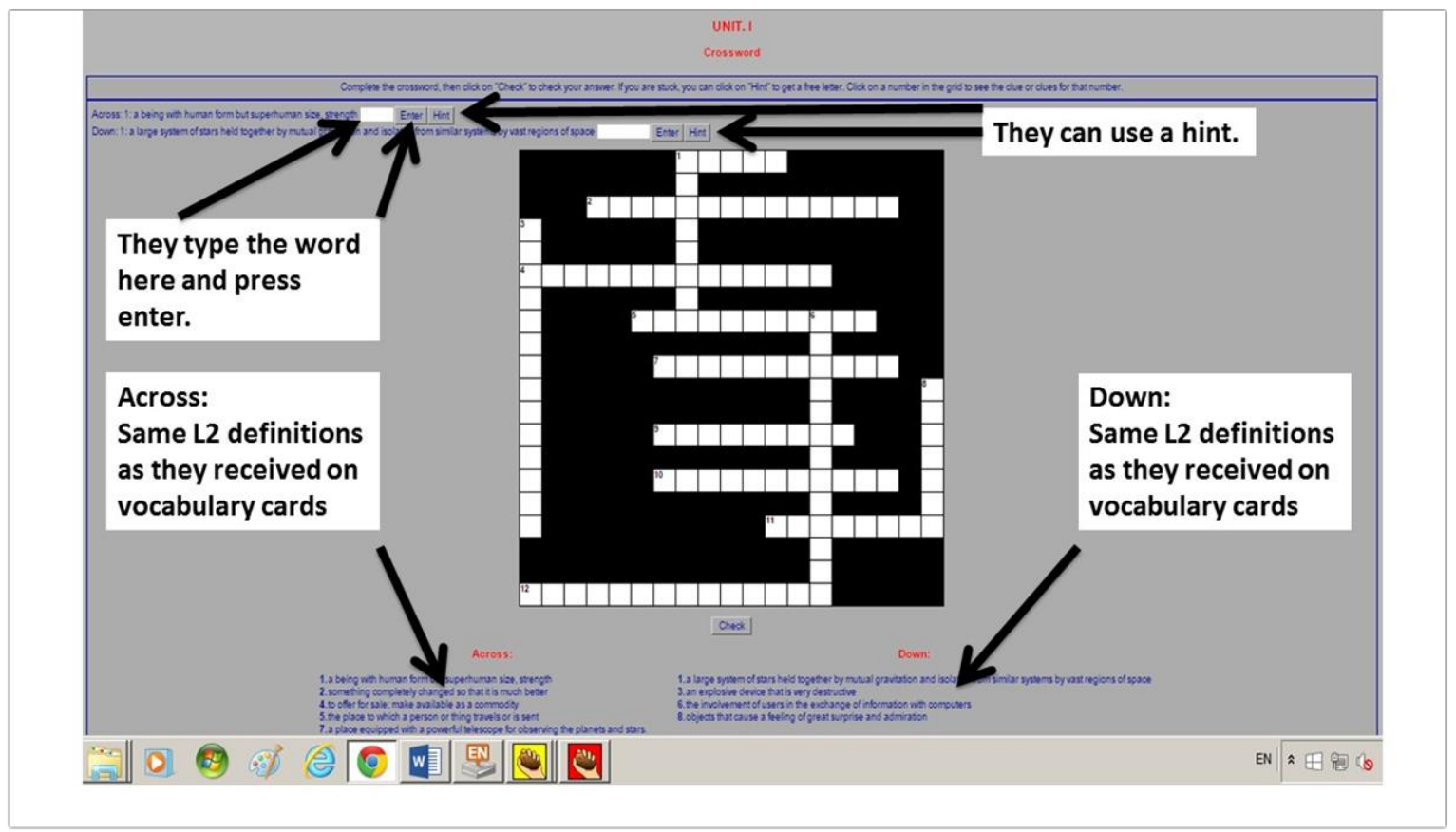

\subsection{Data Collection Instrument}

Figure 3. A screen shot of crossword puzzle

The study used an achievement test which was prepared by researcher (Ary, Jacobs, Sorensen, \& Walker, 2013; Brislin, 1986). The instrument preparation had three phases. In the first phase, researcher wrote 30 multiple choice items (Basoglu \& Akdemir, 2010; Milton, 2009) to test vocabulary. In the second phase the test was sent to ten expert teachers who had vast experience in EFL instruction and testing. The test was revised in the light of their suggestions. Twenty items were selected for inclusion in the final test. In the third phase, the test was piloted on 31 students who were at the similar level of language proficiency (Fraenkel et al., 1993) as were the subjects of the study. The test was given twice to the same group with an interval of two weeks to verify its consistency. Following section describes the results of pilot study (Van Teijlingen \& Hundley, 2001) in detail.

\subsection{Pilot Study}

As described in the previous section the instrument was developed by the researcher. To ascertain its reliability and validity it was thoroughly tested. In this section the results of the pilot study are reported.

Table 1. Descriptive Statistics of pilot study

\begin{tabular}{llllllll}
\hline Descriptive Statistics & & & & & \\
& N & Range & Minimum & Maximum & Mean & & Std. \\
& Statistic & Statistic & Statistic & Statistic & Statistic & Std. Error & Statistic \\
& 31 & 15 & 1 & 16 & 7.68 & .702 & 3.911 \\
& 31 & 13 & 4 & 17 & 9.52 & .564 & 3.140 \\
First Test & 31 & & & & & & \\
Second Test & & & & & & & \\
Valid N & (listwise) & & & & & &
\end{tabular}


Table 1 displays the mean score of the group $(N=31)$ was 7.68 on first attempt $(M=7.68)$, equal to $38.4 \%$ of the full score of 20 points. Minimum score was 1, equivalent to about $5 \%$ of full score and maximum score was 16 , which is $80 \%$ of the full score. Standard deviation was $3.91(S D=3.91)$. Second administration produced slightly better results. The group mean score was $9.52(M=$ 9.52) which accounts for $47.6 \%$ of the full score of 20 points. Minimum score was 4 , equivalent to $20 \%$ of full score and maximum score was 17 , which is $85 \%$ of the full score. Standard deviation was $3.14(S D=3.14)$. Better performance in the second attempt may be because of the fact that it was their second attempt to take the same test in two weeks. Higher standard deviation indicated that the group was heterogeneous.

Table 2. Pearson Correlation Results

\begin{tabular}{llll}
\hline Correlations & & & \\
\hline \hline & & First Test & Second Test \\
\hline First Test & Pearson & 1 & $.923^{* * *}$ \\
& Correlation & & .000 \\
& Sig. (2-tailed) & 31 & 31 \\
& N & 31 & 1 \\
\hline Second Test & Pearson & $.923^{* *}$ & \\
& Correlation & .000 & 31 \\
& Sig. (2-tailed) & 31 & \\
& N & 31 the 0.01 level (2- \\
\hline \hline
\end{tabular}

As presented in table 2 a Pearson product-moment correlation coefficient was calculated to measure the consistency and reliability of two test administrations. There was a positive correlation between the two test scores, $(r=0.923, n=31, p=0.000, p<0.01)$.

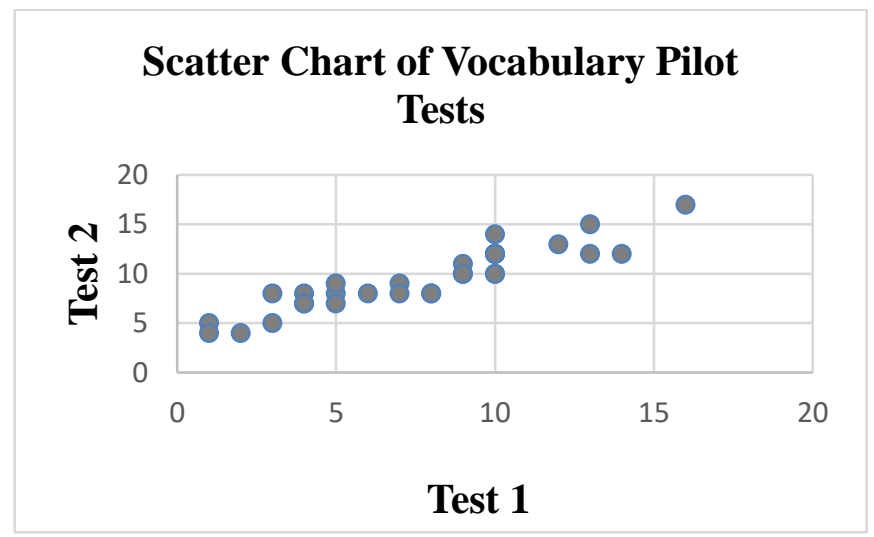

Figure 4. Scatter chart of pilot study

A scatterplot summarizes the results (Figure 4). Overall, there was a strong, positive correlation between two separate administrations of the test. Since the test was multiple choice where 1 credit was allowed for each correct answer and 0 for wrong answer, to ensure inter item consistency and reliability Kuder and Richardson Formula 20 was used. The results were $\rho$ KR20 $=0.702$. The results indicated that test was reliable. Thus, after ensuring the validity and reliability of the instrument for data collection the study proceeded. Following section describes data collection procedures and reports the results of pretest and posttest.

\section{Results}

\subsection{Pretest}

A pretest was administered in the outset of study to determine the equivalence of groups. Participants were divided into four groups, two groups from male campus and two from female campus. One group from each campus male $(N=31)$ and female $(N=30)$ was assigned to experimental condition and one group male $(N=30)$ and female $(N=31)$ was used as comparison.

Table 4. Descriptive statistics of Pretest

\begin{tabular}{llllll}
\hline Group Statistics & & & & \\
& & & & Std. & Std. Error \\
& Students I & N & Mean & Deviation & Mean \\
\hline Pretest & Control Group & 61 & 7.11 & 2.114 & .271 \\
Vocabulary & Treatment & 61 & 7.20 & 1.759 & .225 \\
Score & Group & & & & \\
\hline \hline
\end{tabular}

As table 4 shows control group $(N=61)$ had a mean score of $7.11(M=7.11)$ which was $35.5 \%$ of full score of 20 points and standard deviation was $2.11(S D=2.11)$. Standard error of means was $0.27(S E M=0.27)$. On the other hand mean score of treatment group $(N$ $=61)$ was $7.20(M=7.20)$ which was $36 \%$ of full score of 20 points and standard deviation $1.75(S D=1.75)$. Standard deviation is a measure of dispersion of scores from mean score. Standard error of means was $0.22(S E M=0.22)$. 


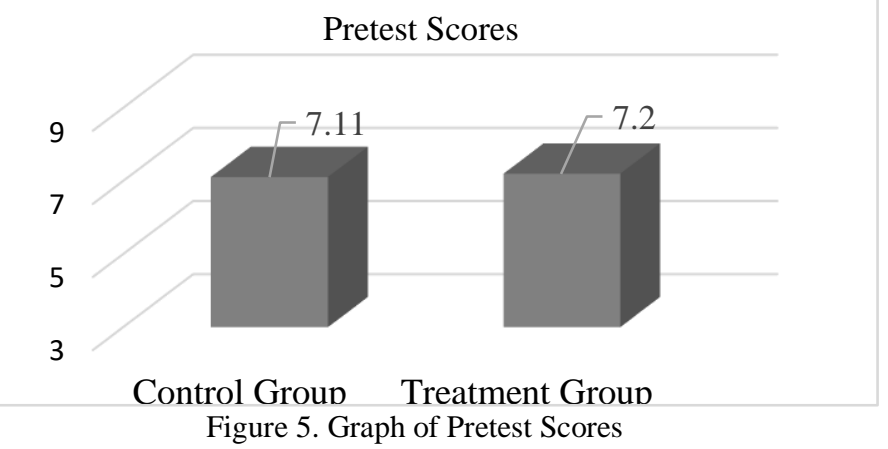

As depicted in figure 5 the score of treatment group and control group was almost identical. There was a small numerical difference in the mean scores of two groups which was analyzed for statistical significance through independent samples t-test. The results are presented in table 5 below.

Table 5. Inferential Statistics of the Pretest

\begin{tabular}{|c|c|c|c|c|c|c|c|c|c|c|}
\hline \multicolumn{11}{|c|}{ Independent Samples Test } \\
\hline & & \multicolumn{2}{|c|}{$\begin{array}{l}\text { Levene's Test for Equality } \\
\text { of Variances }\end{array}$} & \multicolumn{5}{|c|}{ t-test for Equality of Means } & \multirow{2}{*}{\multicolumn{2}{|c|}{$\begin{array}{l}95 \% \text { Confidence Interval of } \\
\text { the Difference }\end{array}$}} \\
\hline & & & & & & Sig. (2- & Mean & Std. Error & & \\
\hline & & $\mathrm{F}$ & Sig. & t & df & tailed) & Difference & Difference & Lower & Upper \\
\hline \multirow{2}{*}{$\begin{array}{l}\text { Pretest } \\
\text { Vocabulary } \\
\text { Score }\end{array}$} & $\begin{array}{l}\text { Equal variances } \\
\text { assumed }\end{array}$ & 1.440 & .232 & -.233 & 120 & .816 & -.082 & .352 & -.779 & .615 \\
\hline & $\begin{array}{l}\text { Equal variances } \\
\text { not assumed }\end{array}$ & & & -.233 & 116.156 & .816 & -.082 & .352 & -.779 & .615 \\
\hline
\end{tabular}

Levene's test was run to ascertain equality of variances. The results show $(p=.232$, with $\alpha=0.05)$ which meant that variances were homogeneous. To compare means independent samples t-test was done with $(\alpha=0.05)$. The $p$ value was $(p=0.816)$ which meant that there was no statistically significant difference between the mean scores of the treatment group and the control group. The result was very important for the study as it validated the assumption that two groups were at the same level of language proficiency at the start of the treatment. It provided the standard against which the differences in the performances of the treatment group and the control group at the conclusion of treatment were measured.

\subsection{Posttest Results}

To answer the first research question "What Impact does the Hybrid Model have on the EFL vocabulary learning of students on Preparatory Year Program (PYP) at a public university?" the posttest results of the control group and the treatment group were compared. Next, the analysis of posttest results is presented.

Table 6. Descriptive Statistics of the Posttest

\begin{tabular}{|c|c|c|c|c|c|}
\hline \multicolumn{6}{|c|}{ Group Statistics } \\
\hline & Students ID & $\mathrm{N}$ & Mean & $\begin{array}{l}\text { Std. } \\
\text { Deviation }\end{array}$ & $\begin{array}{l}\text { Std. Error } \\
\text { Mean }\end{array}$ \\
\hline \multirow{2}{*}{$\begin{array}{l}\text { Posttest } \\
\text { Vocabulary } \\
\text { Score }\end{array}$} & Control Group & 61 & 9.30 & 1.909 & .244 \\
\hline & $\begin{array}{l}\text { Treatment } \\
\text { Group }\end{array}$ & 61 & 10.48 & 1.766 & .226 \\
\hline
\end{tabular}

As presented in table 6 the mean score for the control group $(N=61)$ was $9.30(M=9.30)$ which is $46.5 \%$ of maximum score of 20 . Standard deviation was $1.90(S D=1.90)$. Standard error mean was $0.24(S E M=0.24)$. Mean score of the treatment group $(N=61)$ was $10.48(M=10.48)$ which is $52.4 \%$ of maximum score of 20 . Standard deviation was $1.76(S D=1.76)$ while standard mean error was $0.22(S E M=0.22)$.

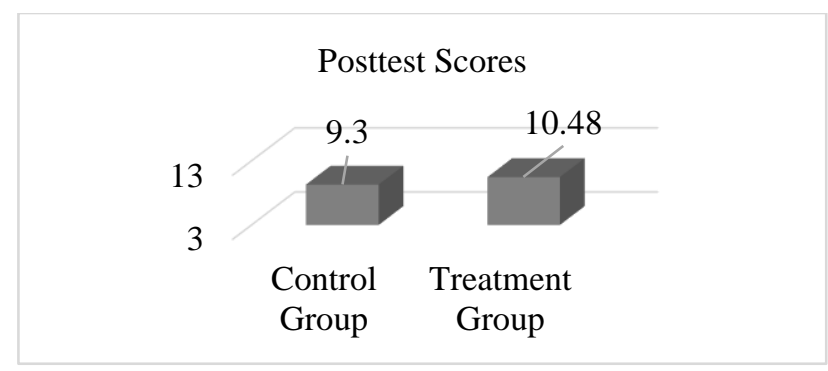

Figure: 6. Graph of Posttest Scores

Figure 6 gives the same information in graphical form. The treatment group showed better performance than did the control group. As shown in figure 6 there was a numerical difference of 1.18 between the groups. Levene's test was run to verify assumption of homogeneity of variances. Independent sample t-test was run to see if the mean difference was significant. Results are presented in table 7 below. 


\begin{tabular}{|c|c|c|c|c|c|c|c|c|c|c|}
\hline \multicolumn{11}{|c|}{ Independent Samples Test } \\
\hline & & \multicolumn{2}{|c|}{$\begin{array}{l}\text { Levene's Test for Equality } \\
\text { of Variances }\end{array}$} & \multicolumn{5}{|c|}{ t-test for Equality of Means } & \multirow{2}{*}{\multicolumn{2}{|c|}{$\begin{array}{l}95 \% \text { Confidence Interval of } \\
\text { the Difference }\end{array}$}} \\
\hline & & & & & & Sig. (2- & Mean & Std Error & & \\
\hline & & $\mathrm{F}$ & Sig. & $\mathrm{t}$ & df & tailed) & Difference & Difference & Lower & Upper \\
\hline \multirow{2}{*}{$\begin{array}{l}\text { Posttest } \\
\text { Vocabulary } \\
\text { Score }\end{array}$} & $\begin{array}{l}\text { Equal variances } \\
\text { assumed }\end{array}$ & .417 & .520 & -3.544 & 120 & .001 & -1.180 & .333 & -1.840 & -.521 \\
\hline & $\begin{array}{l}\text { Equal variances } \\
\text { not assumed }\end{array}$ & & & -3.544 & 119.283 & .001 & -1.180 & .333 & -1.840 & -.521 \\
\hline
\end{tabular}

Levene's test results show $(p=.520$, with $\alpha=0.05)$ which verifies the assumption that variances were equal. In t-test the value of $\mathrm{p}$ was $0.001(p=0.001, \alpha=0.05)$. The $p$ value was less than $0.05(p=0.000, \alpha=0.05)$ which meant that the difference between the control group and the treatment group means was statistically significant. Cohen's d for effect size was estimated at $(d=0.64)$ which according to (Cohen, 1992) was a medium to large effect size. Therefore, in the light of this result, null hypothesis $\left(\mathrm{H}_{0}\right)$, the Hybrid Model has no impact on the EFL vocabulary learning of students on Preparatory Year Program (PYP) at a public university.is rejected. The alternate hypothesis $\mathrm{H}_{1}$, the Hybrid Model has an impact on the EFL vocabulary learning of students on Preparatory Year Program (PYP) at a public university, is accepted.

To answer the second question "How does the Hybrid Model effect the EFL vocabulary learning of male and female learners on Preparatory Year Program (PYP) at a public university?" the posttest scores of the treatment group (male) and the treatment group (female) were analyzed.

Table 8. Descriptive Statistics of Treatment Groups

\begin{tabular}{cccccc}
\hline Group Statistics & ID & $\mathrm{N}$ & Mean & Std. Deviation & $\begin{array}{c}\text { Std. Errors } \\
\text { Mean }\end{array}$ \\
\hline \hline $\begin{array}{c}\text { Posttest } \\
\text { Vocabulary } \\
\text { Score }\end{array}$ & $\begin{array}{c}\text { Treatment } \\
\text { (Male) } \\
\text { Treatment } \\
\text { (Female) }\end{array}$ & 30 & 10.63 & 1.712 & .313 \\
\hline \hline
\end{tabular}

Table 8 presents the posttest scores of the male and the female treatment groups. Mean score of the treatment group $($ male $)(N=30)$ was $10.63(M=10.63)$. Standard deviation was $1.71(S D=1.71)$. Standard mean error was $0.31(S E M=0.31)$. Mean score of the treatment group (female) $(N=31)$ was $10.32(M=10.32)$. Standard deviation was $1.83(S D=1.83)$. Standard mean error was 0.32 $(S E M=0.32)$.

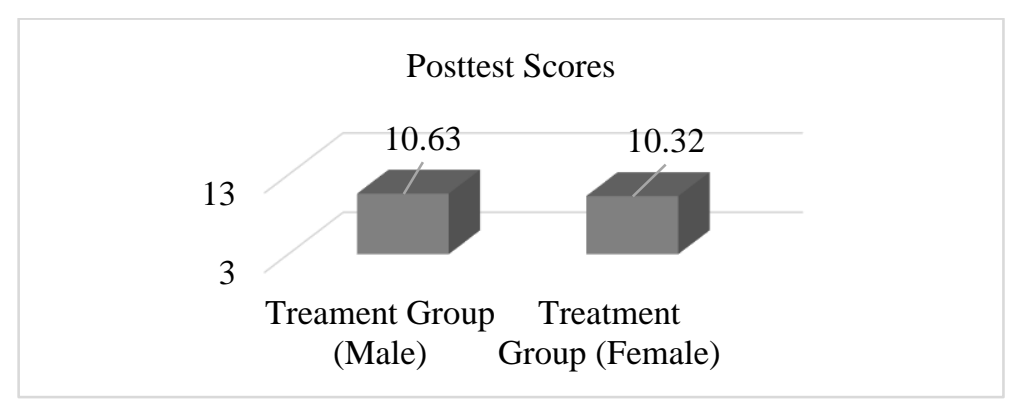

Figure 7. Graph of the Treatment Groups' Posttest Scores

As displayed in figure 7 the performance of both groups in the posttest was quite similar. Difference in mean score was very small. However t-test was conducted to ascertain that it was statistically significant or not. Table 9 below presents the results these inferential statistical measures.

Table 9. Inferential Statistics on the Pretest Scores of Male and Female Treatment Groups

\begin{tabular}{|c|c|c|c|c|c|c|c|c|c|c|}
\hline \multicolumn{11}{|c|}{ Independent Samples Test } \\
\hline & & \multicolumn{2}{|c|}{$\begin{array}{l}\text { Levene's Test for Equality } \\
\text { of Variances }\end{array}$} & \multicolumn{5}{|c|}{ t-test for Equality of Means } & \multirow{2}{*}{\multicolumn{2}{|c|}{$\begin{array}{l}95 \% \text { Confidence Interval of } \\
\text { the Difference }\end{array}$}} \\
\hline & & & & & & Sig. (2- & Mean & Std. Error & & \\
\hline & & $\mathrm{F}$ & Sig. & $t$ & $\mathrm{df}$ & tailed) & Difference & Difference & Lower & Upper \\
\hline \multirow{2}{*}{$\begin{array}{l}\text { Posttest } \\
\text { Vocabulary } \\
\text { Score }\end{array}$} & $\begin{array}{l}\text { Equal variances } \\
\text { assumed }\end{array}$ & .139 & .710 & .684 & 59 & .497 & .311 & .454 & -.599 & 1.220 \\
\hline & $\begin{array}{l}\text { Equal variances } \\
\text { not assumed }\end{array}$ & & & .685 & 58.928 & .496 & .311 & .454 & -.598 & 1.219 \\
\hline
\end{tabular}

Levene's test was associated with equivalence of variances. The results indicated $(p=.710$, with $\alpha=0.05)$ which verifies the assumption that variances were equal. In t-test the value of $p$ was $0.497(p=0.497, \alpha=0.05)$. The $p$ value was greater than $0.05(p=0.497, \alpha=$ 0.05 ) which meant that the difference between control group and treatment group means was statistically not significant. In the light of this result the null hypothesis $\mathrm{H}_{0}$ that the impact of the Hybrid Model on the EFL vocabulary learning of students on Preparatory Year Program (PYP) at a public university, is gender neutral, is accepted. It is concluded that the treatment seemed beneficial for both genders. 


\section{Discussion}

The study endeavoured to evaluate the effectiveness of a Hybrid Model, created through computer and mobile phone affordances, for EFL vocabulary learning of the freshmen at a public university. The basic assumptions of the study were based on Dual Coding Theory (DCT) (Clark \& Paivio, 1991), Schema Theory (Bartlett \& Bartlett, 1995) and Second Language Acquisition Theory (Krashen, 1982). In line with DCT, the study tried to present vocabulary in way that had appeal for both hypothyzed division of cognition i.e. language oriented and image oriented. The glosses used in the study were both textual and pictorial. From Schema Theory point of view, the study tried to take advantage of technology to present pictorial information alongwith texual information. It is argued that pictorial glosses can help in activation of schemata. Furthermore, the learners can connect more easily with their stored knowledge when the presented information reminds them what they already know than when they need to concentrate and look for matching information in their memories. From stand point of SLA theory, the input was made comprehensible with the help of glosses and it was delivered in an extremely low Affective Filter (Krashen, 1982) environment. The students received vocabulary on their mobile phones when they were off campus. This input could be accessed whenever and wherever the learners chose. It is argued that the freedom of choice offered in this study almost totally eliminated the elements of anxiety, fear and boredom.

The results of the present study are comaparable with the study by $\mathrm{Wu}$ (2015). The study used a specially written mobile phone application for teaching 3402 words. The participants in the experimental condition had access to the application anywhere anytime and they used it for learning vocabulary items in their own self-regulated way. On the other hand the participants in the control condition learned same materials through traditional ways. It reported a net gain of $8.49 \%$ over the control group's performance. The present study used a better technique as compared to Wu's study in that it used a social networking application for vocabulary instruction. It is argued that the technique used in the present study was more cost effective. From pedagogical perspective too, the present study was better because the treatment was more contextualised than the treatment in (Wu, 2015). Additionally, the results of another study by Zhang, Song, and Burston (2011) were also similar to the present study. The study had 62 subjects who were divided into two groups, experimental and control. The material used was a list of 130 words made salient with phonetic transcription, L1 definition and an example sentence. Like present study the lexical items were delivered through a mobile phone application which was free of cost. The treatment group scored $8.7 \%$ better than did the control group which is also comparable with the present study where the treatment group recorded a comparative advantage of about $6 \%$ over the control group.

The results of the second research question "How does the Hybrid Model effect the EFL vocabulary learning of male and female learners on Preparatory Year Program (PYP) at a public university?" are comparable with the study by Alavinia and Qoitassi (2013). The participants in this study were all female. They were taught vocabulary through standard mobile phone SMS. The results were in favour of such a method of instruction as the treatment group out-performed their counterparts in the control group. Likewise the female participants in the treatment group in the present study showed improved performance as compared to their counterparts in the control group. Moreover, Motallebzadeh and Ganjali (2011) reported results similar to the present study. The participants in their study were all female. The treatment given through SMS proved helpful in learning EFL vocabulary like it was the case in the present study.

The study validated the results of earlier research on the topic. It also added an important piece of information to the body of knowledge on the subject that vocabulary can be glossed and delivered through means that are both inexpensive and easy to use. The treatment was devised in an innovative way. Only cost incurred was researcher's time. Rapid advancements in technology have had one negative impact that latest technologies are touted as the best but only as long as they are superseded by newer ones. If technology is to be used as an assistive tool in educational process it can't be done at the feverish pace of industrial growth. On the contrary, it is argued that existing pieces of technology can be assembled to create a similar model as used in this study to the advantage of the learning process. The type of intervention used in this study is free and easy to assemble, customise and administer. It has the promise of reducing teacher's unnessary workload and it offers an opportunity to the learners to practice input in the time and place of their choice. When learners engage in learning activities in this kind of low filter environment, learning becomes fun and not a burden.

\section{Conclusion}

The present study was undertaken to evaluate the use of technology in vocabulary instruction at a public university in the Kingdom of Saudi Arabia. The basic assumptions were that technology enhanced language learning has the promise of delivering valuable help in the learning process. The literature reviewed points to this direction. A model of intervention was designed by using freely available technical resources. The tasks were delivered in a low Affective Filter environment. The finding of the study were enc ouraging. They were in line with a growing body of evidence that such interventions have potential to help learners learn EFL vocabulary and thereby remove a huge stumbling block out of their way in the reading process.

\subsection{Implications}

The study has important pedagogical implications. Firstly, well planned and designed tasks presented in a low filter environment have the promise of promoting not only language learning but can also promote love for learning. Secondly, expecting miracles from technology had been misleading but neglecting its potential will be a greater mistake. Thirdly, teachers' need training in innovating use of technology that is easily available.

There are some implications for the administrators. They need to encourage teachers to use available technology instead of running after expensive software and fantastic systems which at the time of sale promise miraculous results but in practice prove another dead investment.

Social implications of the study include its use of social networking application for learning purposes. Used innovatively the technique has the promise of changing the very way people learn.

\subsection{Limitations}

Like any other enquiry, the present study has its own limitations. Firstly, a true experiment could not be done because the sample could not be drawn randomly. Secondly, sample size was small. Thirdly, it was conducted at one location. Fourthly, it used a researcher developed instrument for data collection because no standardized instrument compatible with the context of the study could be located. There was a possibility of contamination as the vocabulary was sent to students on their mobile phones which they could easily share with students in the control group. Although they were explicitly told not to do that but there was no mechanism to ensure compliance. 


\subsection{Future Research}

The study might be replicated with bigger and if possible randomized sample. Efforts may be made to develop standardized instruments for this type of studies. Research is needed in identifying critical vocabulary for pre-teaching. Ways of incorporating other skills like writing and listening may be explored.

\section{References}

Abdullah, M. R. T. L., Hussin, Z., Asra, B., \& Zakaria, A. R. (2013). MLearning scaffolding model for undergraduate English language learning: bridging formal and informal learning. TOJET: The Turkish Online Journal of Educational Technology, 12(2), $217-233$. AbuSeileek, A. F. M. (2008). Hypermedia annotation presentation: Learners' preferences and effect on EFL reading comprehension and vocabulary acquisition. CALICO Journal, 25(2), 260-275.

Al-Jarf, R. (2007). Teaching vocabulary to EFL college students online. CALL-EJ Online, 8(2), 8-2.

Al Shekaili, B. (2016). Investigating teachers' actual levels of use of WhatsApp application with English foundation and credit program students at Sultan Qaboos University in Oman. Journal of Teaching English for Specific and Academic Purposes, 4(1), 39-48.

Alavinia, P., \& Qoitassi, K. (2013). On the viability of vocabulary learning enhancement through the implementation of MALL: The case of Iranian EFL learners. Journal of Language Teaching and Research, 4(2), 412-426.

Alemi, M., Sarab, M. R. A., \& Lari, Z. (2012). Successful learning of academic word list via MALL: Mobile assisted language learning. International Education Studies, 5(6), 99-109.

Ary, D., Jacobs, L., Sorensen, C., \& Walker, D. (2013). Introduction to research in education (8th ed.). Belmont: Cengage Learning. August, G. (2011). Spelling facilitates good ESL reading comprehension. Journal of Developmental Education, 35(1), 14-24.

Azari, F., Abdullah, F. S., Heng, C. S., \& Hoon, T. B. (2012). Effects of glosses on vocabulary gain and retention among tertiary level EFL learners. Retrieved from http://files.eric.ed.gov/fulltext/ED533228.pdf

Barrot, J. S. (2013). Revisiting the role of linguistic complexity in ESL reading comprehension. 3L: Language, Linguistics and Literature, The Southeast Asian Journal of English Language Studies., 19(1), 5-18.

Bartlett, F. C., \& Bartlett, F. C. (1995). Remembering: A study in experimental and social psychology (Vol. 14): Cambridge University Press.

Basoglu, E. B., \& Akdemir, O. (2010). A comparison of undergraduate students' English vocabulary learning: Using mobile phones and flash cards. Turkish Online Journal of Educational Technology-TOJET, 9(3), 1-7.

Beechler, S., \& Williams, S. (2012). Computer assisted instruction and elementary ESL students in sight word recognition. International Journal of Business and Social Science, 3(4), 85-92.

Birch, B. M. (2014). English L2 reading: Getting to the bottom: Routledge.

Brislin, R. W. (1986). The wording and translation of research instruments. In W. J. Lonner \& J. W. Berry (Eds.), Field methods in cross-cultural research (pp. 137-164). Beverly Hills, CA: Sage.

Burt, M., Peyton, J. K., \& Van Duzer, C. (2005). How should adult ESL reading instruction differ from ABE reading instruction. Center for Adult English Language Acquisition. Retrieved from http://www.cal.org/caela/esl_resources/briefs/readingdif.html Chapelle, C. A. (2001). Computer applications in second language acquisition: Cambridge University Press.

Chen, I., \& Yen, J. C. (2013). Hypertext annotation: Effects of presentation formats and learner proficiency on reading comprehension and vocabulary learning in foreign languages. Computers \& Education, 63, 416-423.

Chen, N. S., Hsieh, S. W., \& Kinshuk, A. (2008). Effects of short-term memory and content representation type on mobile language learning. Language Learning \& Technology, 12(3), 93-113.

Chickering, A. W., \& Ehrmann, S. C. (1996). Implementing the seven principles: Technology as lever. AAHE bulletin, 49, 3-6.

Chun, D. M., \& Plass, J. L. (1996). Effects of multimedia annotations on vocabulary acquisition. The Modern Language Journal, 80(2), 183-198.

Clark, J. M., \& Paivio, A. (1991). Dual coding theory and education. Educational Psychology Review, 3(3), 149-210.

Cohen, J. (1992). A power primer. Psychological Bulletin, 112(1), 155-159.

Demouy, V., \& Kukulska-Hulme, A. (2010). On the spot: Using mobile devices for listening and speaking practice on a French language programme. Open Learning, 25(3), 217-232.

Dina, A. T., \& Ciornei, S. I. (2013). The advantages and disadvantages of computer assisted language learning and teaching for foreign languages. Procedia-Social and Behavioral Sciences, 76, 248-252.

Dulay, H., \& Burt, M. (1978). Remarks on creativity in language acquisition. In W. C. Ritchie (Ed.), Second language acquisition research: Issues and implications (pp. 65-89). San Diego, CA: Academic Press.

Duman, G., Orhon, G., \& Gedik, N. (2015). Research trends in mobile assisted language learning from 2000 to 2012. ReCALL, 27(02), 197-216.

Ecalle, J., Kleinsz, N., \& Magnan, A. (2013). Computer-assisted learning in young poor readers: The effect of grapho-syllabic training on the development of word reading and reading comprehension. Computers in Human Behavior, 29(4), 1368-1376.

Ecalle, J., Magnan, A., \& Calmus, C. (2009). Lasting effects on literacy skills with a computer-assisted learning using syllabic units in low-progress readers. Computers \& Education, 52(3), 554-561.

Fraenkel, J. R., Wallen, N. E., \& Hyun, H. H. (1993). How to design and evaluate research in education (Vol. 7). New York: McGrawHill.

Gorjian, B. (2012). Teaching Vocabulary through Web-Based Language Learning (WBLL) Approach. Procedia Technology, 1, 334339.

Han, Z., \& Chen, C. L. A. (2010). Repeated-reading-based instructional strategy and vocabulary acquisition: A case study of a heritage speaker of Chinese. Reading in a Foreign Language, 22(2), 242-262.

Hayati, A., Jalilifar, A., \& Mashhadi, A. (2013). Using short message service (SMS) to teach English idioms to EFL students. British Journal of Educational Technology, 44(1), 66-81.

Hirschel, R., \& Fritz, E. (2013). Learning vocabulary: CALL program versus vocabulary notebook. System, 41(3), 639-653.

Hussain, M. (2011). The effect of mediated glosses on vocabulary retention and reading comprehension with English language learners in Saudi Arabia. (Doctral Dissertation), University of Kansas, USA.

Jarvis, H. (2015). From PPP and CALL/MALL to a praxis of task-based teaching and mobile assisted language use. Teaching English as a Second or Foreign Language Electronic Journal, 19(1), 1-10. 
Jarvis, H., \& Achilleos, M. (2013). From computer assisted language learning (CALL) to mobile assisted language use (MALU). TESLEJ, 16(4), 1-18.

Johnson, E. P., Perry, J., \& Shamir, H. (2010). Variability in reading ability gains as a function of computer-assisted instruction method of presentation. Computers \& Education, 55(1), 209-217.

Jones, R. G. (2011). Emerging technologies: Mobile apps for language learning. Language Learning \& Technology, $15(2), 2-11$.

Kang, Y., Kang, H. S., \& Park, J. (2012). Is it vocabulary breadth or depth that better predict Korean EFL learners' reading comprehension. English Teaching, 67(4), 149-171.

Kim, H., \& Kwon, Y. (2012). Exploring smartphone applications for effective mobile-assisted language learning. Multimedia-Assisted Language Learning, 15(1), 31-57.

Kim, H. S. (2011). Effects of SMS text messaging on vocabulary learning. Multimedia Assisted Language Learning, 14(2), 159-180.

Krashen, S. D. (1981). Second language acquisition and second language learning: Oxford University Press.

Krashen, S. D. (1982). Principles and practice in second language acquisition. UK: Oxford Pergamon.

Kukulska-Hulme, A., \& Shield, L. (2008). An overview of mobile assisted language learning: From content delivery to supported collaboration and interaction. ReCALL, 20(03), 271-289.

Lai, A. (2016). Mobile immersion: an experiment using mobile instant messenger to support second-language learning. Interactive Learning Environments, 24(2), 277-290.

Lems, K., Miller, L. D., \& Soro, T. M. (2009). Teaching reading to English language learners: Insights from linguistics. New York: Guilford Press.

Lin, C. C., Hsiao, H. S., Tseng, S. p., \& Chan, H. j. (2014). Learning English vocabulary collaboratively in a technology-supported classroom. Turkish Online Journal of Educational Technology, 13(1), 162-173.

Lu, M. (2008). Effectiveness of vocabulary learning via mobile phone. Journal of Computer Assisted Learning, 24(6), 515-525.

Marzban, A. (2011). Investigating the role of multimedia annotations in EFL reading comprehension. Procedia-Social and Behavioral Sciences, 28, 72-77.

Miangah, T. M., \& Nezarat, A. (2012). Mobile-assisted language learning. International Journal of Distributed and Parallel Systems, 3(1), 309-319.

Milton, J. (2009). Measuring second language vocabulary acquisition. Bristol, UK: Multilingual Matters.

Moinzadeh, A., \& Moslehpour, R. (2012). Depth and breadth of vocabulary knowledge: Which really matters in reading comprehension of Iranian EFL learners? Journal of Language Teaching and Research, 3(5), 1015-1026.

Montero Perez, M., Van Den Noortgate, W., \& Desmet, P. (2013). Captioned video for L2 listening and vocabulary learning: A metaanalysis. System, 41(3), 720-739.

Morris, N. O. (2011). Using technology in the EFL classroom in Saudi Arabia. DigitalCollections@SIT, 1(1), 1-51.

Motallebzadeh, K., \& Ganjali, R. (2011). SMS: Tool for L2 vocabulary retention and reading comprehension ability. Journal of Language Teaching and Research, 2(5), 1111-1115.

Mustafa, H. R., Sain, N., \& Razak, N. Z. A. (2012). Using Internet for learning vocabulary among second language learners in a suburban school. Procedia-Social and Behavioral Sciences, 66, 425-431.

Nation, P., \& Meara, P. (2002). Vocabulary. In N. Schmitt (Ed.), An introduction to applied linguistics. London: Arnold.

Nikoopour, J., \& Kazemi, A. (2014). Vocabulary Learning through Digitized \& Non-digitized Flashcards Delivery. Procedia-Social and Behavioral Sciences, 98, 1366-1373.

Oz, H. (2015). An investigation of preservice English teachers' perceptions of mobile assisted language learning. English Language Teaching, 8(2), 22-35.

Palalas, A. (2011). Mobile-assisted language learning: Designing for your students. In S. Thouësny \& L. Bradley (Eds.), Second language teaching and learning with technology: Views of emergent researchers. Dublin, Ireland: Research-publishing.net.

Plana, M. G. C., Gimeno, A., Appel, C., \& Hopkins, J. (2013). Improving learners' reading skills through instant short messages: A sample study using WhatsApp. Paper presented at the 4th World CALL Conference, Glasgow.

Rezaee, A. A., \& Shoar, N. S. (2011). Investigating the effect of using multiple sensory modes of glossing vocabulary items in a reading text with multimedia annotations. English Language Teaching, 4(2), 25-34.

Sandberg, J., Maris, M., \& de Geus, K. (2011). Mobile English learning: An evidence-based study with fifth graders. Computers \& Education, 57(1), 1334-1347.

Soars, L., Soars, J., \& Wheeldon, S. (2014). New headway intermediate student's book: Oxford University Press.

Stockwell, G. (2010). Using mobile phones for vocabulary activities: Examining the effect of the platform. Language Learning \& Technology, 14(2), 95-110.

Stockwell, G., \& Hubbard, P. (2013). Some emerging principles for mobile-assisted language learning. Monterey, CA: The International Research Foundation for English Language Education. Retrieved from http://www.tirfonline.org/english-in-theworkforce/mobile-assisted-language-learning.

Valk, J. H., Rashid, A. T., \& Elder, L. (2010). Using mobile phones to improve educational outcomes: An analysis of evidence from Asia. The International Review of Research in Open and Distributed Learning, 11(1), 117-140.

Van Teijlingen, E., \& Hundley, V. (2001). The importance of pilot studies. Social research update(35), 1-4.

Willis, J. (2008). Teaching the brain to read: Strategies for improving fluency, vocabulary, and comprehension. USA: ASCD Publications.

Wong, L. H. (2012). A learner-centric view of mobile seamless learning. British Journal of Educational Technology, 43(1), 19-23.

Wu, Q. (2015). Pulling mobile assisted language learning (MALL) into the mainstream: MALL in broad practice. PloS One, 10(5), 112.

Yang, J. (2013). Mobile assisted language learning: Review of the recent applications of emerging mobile technologies. English Language Teaching, 6(7), 19-25.

Yun, J. (2011). The effects of hypertext glosses on L2 vocabulary acquisition: A meta-analysis. (Doctoral Dissertation), University of Kansas. Retrieved from

https://kuscholarworks.ku.edu/bitstream/handle/1808/6459/Yun_ku_0099D_10940_DATA_1.pdf?sequence=1\&isAllowed=y

Zaharna, R. S. (1995). Understanding cultural preferences of Arab communication patterns. Public Relations Review, 21(3), $241-255$.

Zhang, H., Song, W., \& Burston, J. (2011). Reexamining the effectiveness of vocabulary learning via mobile phones. TOJET: The

Turkish Online Journal of Educational Technology, 10(3), 203-214. 